\title{
Borrowing Latin American Materials in the Big Ten Academic Alliance: A Case Study for Consortial Data Analysis
}

\section{Hilary H. Thompson, Austin Smith, Manuel Ostos, and Lisa Gardinier}

\begin{abstract}
Inspired by the 2017 Big Ten Academic Alliance Library Conference's collective collection theme, the authors undertook a study to better understand the consortium's resource-sharing needs for Spanish and Portuguese materials published in Latin America. The authors employed multiple technologies to expedite gathering, reconciling, and analyzing data from different sources, making this project an excellent case study for consortial data analysis. In addition to presenting the methodology and key findings, the article encourages academic librarians to use resource-sharing data to inform cooperative collection development in area studies to build distinctive collections supporting consortial and national resource sharing.
\end{abstract}

\section{Introduction}

The Big Ten Academic Alliance (BTAA) Library Initiatives, formerly known as the Committee on Institutional Cooperation's Center for Library Initiatives, is composed of fifteen university libraries that collaborate to optimize access to the group's combined resources while maximizing cost, time, and space savings. The BTAA Interlibrary Loan (ILL) Directors are an active group within this consortium, with a long history of providing reciprocal lending and collaborating to improve services for their users. ${ }^{1}$ In 2011, the BTAA ILL Directors partnered with Relais International and Atlas Systems to develop and implement UBorrow, a hybrid consortial borrowing system that uses several forms of automation to deliver books and other physical materials more quickly and reliably to users across the consortium. UBorrow won the 2012 Rethinking Resource Sharing Innovation Award, and more than 400,000 items were shared during its first five years of operation. ${ }^{2}$ More recently, BTAA ILL directors collaborated with other BTAA colleagues to provide shipping for a new cooperative cataloging program; to develop a vision for next-generation discovery to delivery systems; and to draft protocols for interlibrary lending of special collections materials. ${ }^{3}$

\footnotetext{
${ }^{*}$ Hilary H. Thompson is Director, User Services \& Resource Sharing, at University of Maryland Libraries; email: hthomps1@umd.edu. Austin Smith is Resource Sharing Coordinator at University of Maryland Libraries; email: afsmith@umd.edu. Manuel Ostos is Librarian for Romance Languages and Literatures at Pennsylvania State University Libraries; email: manuel.ostos@psu.edu. Lisa Gardinier is Latin American E Iberian Studies Librarian at University of Iowa Libraries; email: lisa-gardinier@uiowa.edu. @2019 Hilary H. Thompson, Austin Smith, Manuel Ostos, and Lisa Gardinier, Attribution-NonCommercial (http://creativecommons.org/licenses/by-nc/4.0/) CC BY-NC.
} 
In May 2017, the BTAA hosted its annual library conference, for which the theme was the consortium's collective collection. The conference's stated goal was to "explore how member research libraries can move from legacy cooperative collection development activities to a more holistic environment that leverages robust discovery, digitization, delivery, and shared service environments to advance and shape the collective collection." ${ }^{4}$ The inclusion of delivery acknowledges the critical role resource sharing plays in supporting a collective collection by ensuring timely access to materials, irrespective of where they are housed and the institution with which the patron is affiliated. Beyond facilitating delivery, interlibrary loan (ILL) can also provide valuable data to understand patrons' information needs that surpass what their local collection can provide, answering questions such as: How does a consortial collection support the needs of patrons at member libraries? When must they look outside the consortium to fill those needs? Coupled with collections data and the expertise of bibliographers, ILL data can be used to inform strategic cooperative collection development.

While broad efforts to build and support a collective collection are desired, there is a case to be made for greater cooperation in collecting for area studies in particular. International collections are not always well supported or funded, and their selectors have to demonstrate that these collections are needed and used. Moreover, there are numerous barriers to borrowing materials via international ILL, which can impede access to global information resources that are not available within the consortial or national collection. Two presentations at the 2017 BTAA Library Conference were devoted to international collections: Mary Rader (University of Texas) discussed coordinated efforts to build more distinctive local collections of South Asian materials, while Lisa Gardinier (University of Iowa) and Manuel Ostos (Penn State University) presented on ILL use of Spanish-language collections at two BTAA libraries, measuring the impact of consortial memberships on ILL lending. Both presentations were of great interest to Hilary Thompson and Austin Smith, ILL practitioners at the University of Maryland, who were intrigued by the symbiotic possibilities of using ILL data to inform collective collecting, which could in turn improve future resource sharing. Together, Gardinier, Ostos, Smith, and Thompson decided to expand upon the prior work of Gardinier and Ostos, shifting the focus to analyzing ILL borrowing requests for Latin American materials, expanding the scope to include all BTAA member libraries, and employing technology to expedite analysis of these large data sets. Using Latin American materials as a case study, the authors sought to develop a scalable methodology for consortial data analysis that could be used to understand borrowing patterns for publications from specific world regions and to inform cooperative collection development. This methodology was used to answer the following research questions:

1. Which Latin American materials are most requested via ILL by BTAA users?

2. Which BTAA users and institutions are requesting Latin American materials most frequently?

3. What is the success rate for borrowing Latin American materials from other libraries, and are there any particular areas where BTAA users' needs go unmet?

4. To what degree do BTAA libraries rely on the consortial collection and the national collection to obtain Latin American materials requested by their users? 


\section{Literature Review}

New Approaches to Collections and ILL

Academic libraries are currently experiencing significant changes in collection development practices and services due to developments in scholarly communications, open access models, and the availability of and access to ebooks, as well as financial challenges and administrative priorities. Recent literature shows that these shifts in approaches to collections have an impact on or are interconnected with ILL practices and services. In their 2014 analysis of current trends in academic libraries, Dempsey, Malpas, and Lavoie noted a move from institutional-scale development and management of print collections to regional, group-scale consortia. ${ }^{5}$ Similarly, Way stated that "building large stand-alone collections is inefficient and ineffective," and while print collections continue to be important, this collection development model is presented as "unrealistic and unsustainable." ${ }^{\prime}$ As a result, Way argued for a collaborative collection model to provide access to resources via shared approval plans, by demand-driven acquisitions, and large-scale acquisition of ebooks. ${ }^{7}$ While these studies do not identify specific ILL systems, services, or partnerships, ILL support is necessary and implied. Other studies address the relationship between collaborative collections and ILL more explicitly. For example, in his 2015 analysis of collection development practices at Yale University, Dollar discussed the need to move from a stand-alone print collection to a more collaborative model where collections are considered a service. ${ }^{8}$ To illustrate the importance of collaborations, Dollar discussed the Ivy Plus Libraries' BorrowDirect service, a resource-sharing partnership among 13 leading academic libraries using the Relais Discovery to Delivery (D2D) consortial borrowing system, as a sustainable model to support research across institutions.

As a result of the budget cuts and service model changes that accompany these new approaches to collections, ILL services take on greater responsibility and increased pressure to provide the print and online materials requested to support research areas not represented in local collections. Area studies and international collections are particularly affected by these changes, as a significant number of materials used by scholars consist of monographs that are not available in online formats. ${ }^{9}$ While studies provide overviews of shifts from a "just in case" approach to a "just in time" model and from a stand-alone print collection to a more collaborative "collections as a service" approach, they do not individually evaluate foreign language and area and international studies monographs and the challenges associated to the sharing of these materials. ${ }^{10}$

\section{Latin American and International Collections}

In North America, Latin American and other international print materials are most heavily collected by research libraries. While materials published in the United States, Canada, and the United Kingdom are readily collected and available, foreign language collections at the same depth of coverage are much less common, for reasons such as language, labor, and budgets. ${ }^{11}$ As indicated by borrowing activities, these collections primarily support the research activities of faculty and graduate students across a variety of disciplines, especially in the humanities and social sciences, as well as undergraduate research and learning in the target language. ${ }^{12}$ Researchers focusing on international topics are typically accustomed to relying on interlibrary loan for some degree of their source material, which in turn depends on the material being available from another library. ${ }^{13}$ Further, international research requires material from the focus region to provide perspectives and information not published in English. Latin American and 
other international publications not only provide diversity to our collections but more accurately reflect reality on a global scale and meet the needs of research and teaching at our institutions.

\section{Barriers to ILL for International Materials}

Numerous barriers to borrowing materials via international ILL exist, underscoring the importance of not relying solely on this service to meet researchers' needs for global information resources. The Research Libraries Group (RLG) International ILL Task Force survey in 1998 and the Reference and User Services Association's Sharing and Transforming Access to Resources Section (RUSA STARS) international ILL surveys in 2007, 2011, and 2015 reveal not only improvements achieved over the past two decades but also enduring barriers to sharing materials across borders. Foremost among these lasting impediments are the high cost of international shipping, cumbersome payment mechanisms for international transactions, and restrictive policies, while copyright laws and licensing restrictions emerged as significant challenges in 2011 and $2015 .{ }^{14}$ Although college and research libraries in North America may be equipped to overcome the economic barriers associated with international ILL, their ability to borrow materials from abroad is limited by the owning library's ability to lend internationally. Libraries in many countries lack the resources and infrastructure necessary to do so, as evidenced by the correlation Munson and Thompson established between the 2015 RUSA STARS survey respondents' international ILL activity and their countries' development according to the United Nations Human Development Index. ${ }^{15}$

\section{ILL for Latin American Materials}

Specific challenges exist for North American libraries seeking to borrow library materials from Latin America, as the results of Gaffney's 2016 survey of Latin American libraries demonstrate. In addition to the aforementioned economic and legal barriers, Gaffney found that relatively few Latin American libraries participate in the OCLC interlibrary loan network; it may be impossible to locate an email address to otherwise initiate a request; and a formal resource-sharing agreement between institutions may be required to borrow materials, ${ }^{16}$ such as those of the Grupo Amigos and FORO Transfronterizo de Bibliotecas. ${ }^{17}$ These findings reinforce those of Schmidt's 2014 survey of Mexican, Caribbean, Central America, and South American libraries, in which 60 percent of the respondents reported that they did not participate in international ILL, despite advances in other areas of resource sharing. ${ }^{18}$ While Munson and Thompson advocated for academic libraries to pursue several strategies to improve international ILL, ${ }^{19}$ borrowing from consortial and national collections is likely to remain easier, faster, and more cost-effective for the foreseeable future. Ostos and Gardinier in their 2018 data analysis of ILL outbound transactions from Penn State University and University of Iowa found a significant number of Spanish-language loan transactions within the BTAA. ${ }^{20}$ This study suggests the need for an ILL study across all BTAA institutions to support the viability of future and potential collection development collaborations to support Latin American studies research and services within the consortium.

\section{Resource-Sharing Data Analysis in North American Academic Library Consortia}

Most of the literature on resource-sharing data analysis within consortia and other library networks provides broad analysis of transactional data focusing on volume and variables affecting it, ${ }^{21}$ efficacy of the service, ${ }^{22}$ or the status of patrons using the service. ${ }^{23}$ Relatively few articles assess the nature of the materials being borrowed across a consortium beyond the request type (that is to say, loan of a book or other physical material vs. copy of a journal ar- 
ticle or other excerpt). In their 2009 review of a decade of consortial borrowing among the Ivy Plus Libraries, Nitecki, Jones, and Barnett analyzed publication year distribution and the top ten requested titles and authors requested via BorrowDirect. ${ }^{24}$ In 2011, Wiley, Chrzastowski, and Baker examined the subjects and publishers for domestic monographs most frequently borrowed through the College and Research Libraries of Illinois (CARLI)'s I-Share integrated library system. ${ }^{25}$ Analysis of usage by language or country of publication is conspicuously absent from the literature on consortial resource sharing, in some cases with international publications deliberately set aside for future study. ${ }^{26}$ Only a series of studies performed by OCLC Research scientists in partnership with the OhioLINK consortium analyze the language or country of publication. Prabha and O'Neill (2001) and O'Neill and Gammon (2014) examined books requested within OhioLINK in terms of publication date, country, language, and subject, with the latter finding declining use of non-English publications. ${ }^{27}$ None of the existing literature examines the cross-sections of country, language, and subject necessary for nuanced consideration of area studies collections in a consortial context, nor has member libraries' ILL data been used to look at collective users' needs extending beyond the consortial collection.

This gap in the literature likely reflects the complexities of working with a large volume of consortial data. Nitecki, Jones, and Barnett's 2009 assertion that BorrowDirect's "data are not easily coded for an analysis of collection use" still applies to resource-sharing systems nearly a decade later, ${ }^{28}$ and this problem is compounded when analyzing data from multiple systems and networks, such as ILLiad, OCLC WorldshareILL, RapidILL, Relais D2D, and Inn-Reach, all of which are commonly used by U.S. academic libraries. Prabha, O'Neill, and Gammon overcame these challenges by limiting their scope to a single resource-sharing network and used bibliographic data to supplement the resource-sharing data. In terms of methodology, Prabha employed sampling, followed by manual analysis, of OCLC ILL and bibliographic data, ${ }^{29}$ while $\mathrm{O}^{\prime}$ Neill and Gammon matched consortial circulation data to bibliographic records using OCLC number, ISBN, or LCCN, a process described as "complex" and "extensive." ${ }^{30}$ Both studies illustrate the importance of employing scalable techniques to analyze a consortium's resourcesharing data, but neither elucidates which technologies, if any, were used to expedite analysis.

\section{Methodology}

This study focused on ILL borrowing requests for materials published in countries in Central America, South America, and the Caribbean where Spanish or Portuguese is the official and/ or primary language (see table 1) ${ }^{31}$ For the purposes of this article, ILL borrowing requests are defined as requests submitted by a local user that (a) cannot be filled using the library's local collection and (b) are managed within the ILLiad ILL management system. This definition includes UBorrow requests, which are filled within ILLiad alongside traditional ILL requests, but it excludes requests from other consortial borrowing systems due to the improbability of gathering comparable data sets from the diverse statewide and regional systems in which BTAA libraries also participate. Country of publication and language were selected as the primary parameters for this study to facilitate data gathering as well as to enable practical application of the results. Using a language detection algorithm and OCLC country code allowed for greater automation in data collection and analysis. Vendors usually offer materials from a single country or geographic region, and bibliographers from BTAA libraries attend book fairs in Latin America to buy books published in those countries, such the Guadalajara International Book Fair in Mexico, the Bogota International Book fair in Colombia, and the Buenos Aires International Book Fair in Argentina. 


\begin{tabular}{|c|c|c|c|c|}
\hline \multicolumn{5}{|c|}{$\begin{array}{c}\text { TABLE } 1 \\
\text { Countries Included in the Study }\end{array}$} \\
\hline Country & Language & MARC Language Code & MARC Country Code & Location \\
\hline Argentina & es & spa & $\mathrm{ag}$ & South America \\
\hline Bolivia & es & spa & bo & South America \\
\hline Brazil & pt & por & bl & South America \\
\hline Chile & es & spa & $\mathrm{cl}$ & South America \\
\hline Colombia & es & spa & $\mathrm{ck}$ & South America \\
\hline Costa Rica & es & spa & $\mathrm{cr}$ & Central America \\
\hline Ecuador & es & spa & ec & South America \\
\hline El Salvador & es & spa & es & Central America \\
\hline Guatemala & es & spa & gt & Central America \\
\hline Honduras & es & spa & ho & South America \\
\hline Mexico & es & spa & $\mathrm{mx}$ & North America \\
\hline Nicaragua & es & spa & $\mathrm{nq}$ & Central America \\
\hline Panama & es & spa & pn & Central America \\
\hline Paraguay & es & spa & py & South America \\
\hline Peru & es & spa & pe & South America \\
\hline Uruguay & es & spa & uy & South America \\
\hline Venezuela & es & spa & ve & South America \\
\hline Cuba & es & spa & $\mathrm{cu}$ & Caribbean \\
\hline Dominican Republic & es & spa & $\mathrm{dr}$ & Caribbean \\
\hline Puerto Rico & es & spa & $\mathrm{pr}$ & Caribbean \\
\hline
\end{tabular}

The first step was to gather ILL borrowing request data from the fifteen BTAA member libraries. Each library was given a set of four ILLiad custom request searches and a set of four analogous Access queries to gather the data from their local ILL management system (see appendices A and B). Both sets of searches perform SQL queries of the ILLiad database and allow the user to export the results as an Excel spreadsheet; the former is performed in the ILLiad client, while the latter is performed in Microsoft Access using an ODBC data source link. Which method was used depended on the local ILL director's preference, and their choice did not affect the data gathered. The amount of data supplied by each library varied according to local data retention policies, but each library was able to supply between three to six years' worth of recent borrowing request data (with all requests dating from June 1, 2012, to November 30, 2017). Data gathered included the item's title and OCLC number; the request's type (in other words, loan or article), transaction status, and creation date; the user's status (for example: faculty or student); and the lending library that was able to supply the request (if the request was successfully filled).

The next step was to gather metadata from MARC records for relevant ILL requests since information like the item's language (041), country of publication (008), format (leader field), publication date (260 field), and call number (050 field) are more likely to be present and consistently formatted in the records than in the ILL requests. Using the University of Maryland as a test case, the authors examined and rejected other sources for publication information before deciding to use MARC records. While the place of publication may be included in ILLiad's LoanPlace field, only 25 percent of UMD's recent borrowing requests had this information. 
The monthly OCLC Borrower Resource Sharing Stats Reports has imprint information, from which place of publication could be parsed; but, while 81 percent of UMD's OCLC requests had imprint data, sampling showed that not all imprint data contains place of publication. Even if place of publication was always present in the ILLiad or OCLC data, mapping cities to specific Latin American countries would be extremely time consuming for such a large data set and wide array of countries. Moreover, neither ILLiad data nor OCLC resource-sharing reports currently include the publication's language. ${ }^{32}$ Thus, both in terms of data availability and ease of analysis, using the MARC record for publication information was the best option.

To expedite the process of gathering this metadata, Austin Smith developed a Python script that takes as input the titles and OCLC numbers from the ILL borrowing requests. ${ }^{33}$ It attempts to determine the language of each publication by its title using a port of Google's Language Detection Library. ${ }^{34}$ Next, the script uses OCLC's WorldCat Search API to fetch MARC records for each Spanish or Portuguese title, inspects the country and language codes in the MARC records, and saves metadata for Spanish and Portuguese materials published in the twenty Latin American countries included in this study. ${ }^{35}$ Using the Google Language Detection Library to apply an initial limit by language vastly reduced the time involved with fetching MARC records, which was vital given the high volume of BTAA ILL borrowing requests in the data set $(2,732,082$ in all) and the daily limit OCLC places on the number of API calls (50,000 per web service key per day). Relevant information from 23,768 MARC records was gathered using this script.

Of the 2.7 million BTAA ILL borrowing requests, 8,828 lacked an OCLC number. For these requests, the script to identify MARC records was modified by replacing an OCLC number search in the WorldCat API with a title search, then saving metadata for exact title matches (excluding one-word titles) if the language and country code fell within the study's parameters. Using this method, 1,914 additional MARC records describing materials published in Latin America were identified.

Once all the BTAAILL request data and corresponding metadata were gathered, the authors queried the data sets in Microsoft Access to answer questions such as what percentage of requests for Latin American materials are filled within the consortium and what types of materials are our users requesting. In addition to querying each data set individually, the vast majority of the ILLiad data and the associated metadata can be linked using the OCLC number to perform analysis across the two data sets. Querying across the data sets enabled the authors to determine which countries' publications are being requested via ILL most frequently and the degree of success in borrowing certain types of materials. Additionally, expert searches with index labels for country code, library symbol, and/or Library of Congress call number were performed in OCLC's FirstSearch to gather corresponding data for the Big Ten collective collection for comparison. ${ }^{36}$ Ultimately, these queries allowed us to construct a profile for interlibrary loan requesting of Latin American materials in the Big Ten Academic Alliance; articulate our reliance on the consortial and national collection for these publications; and identify any areas of unmet need.

\section{Results and Discussion}

\section{Research Question 1: Which Latin American materials are most requested via ILL by BTAA users?}

Big Ten users requested at least 29,804 Latin American materials in the past six years, which represents 1 percent of total ILL requests. The vast majority ( $88 \%)$ of these requests are for books or chapters, followed by periodicals $(9 \%)$, videos $(2 \%)$, and sound recordings (1\%). Fully 82 


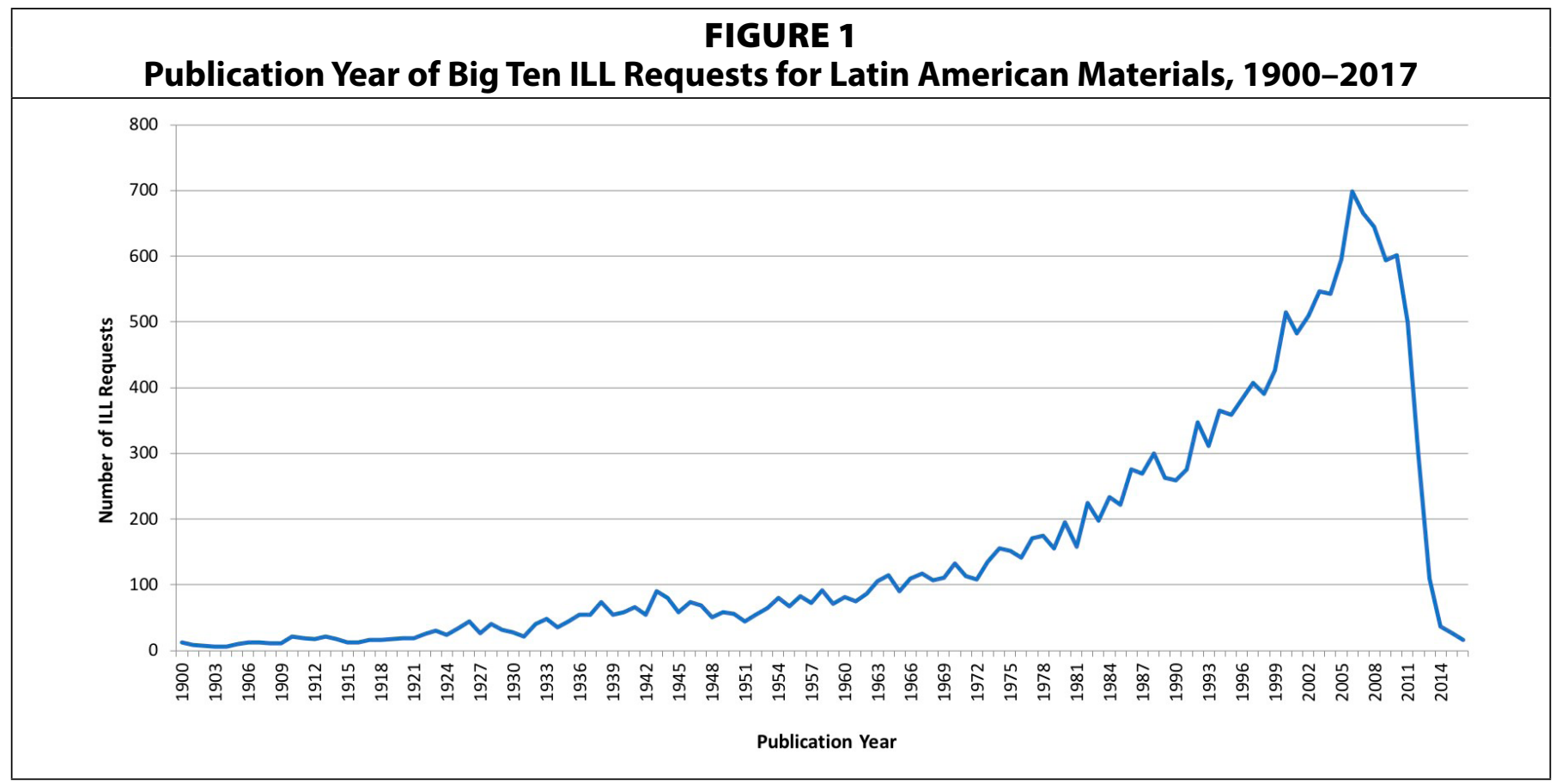

\begin{tabular}{|c|c|c|}
\hline \multicolumn{3}{|c|}{$\begin{array}{c}\text { TABLE } 2 \\
\text { BTAA ILL Requests for Latin American } \\
\text { Materials by Country }\end{array}$} \\
\hline Country & $\begin{array}{l}\text { Number of } \\
\text { ILL } \\
\text { Requests }\end{array}$ & $\begin{array}{l}\text { Percentage of } \\
\text { Latin American } \\
\text { ILL Requests }\end{array}$ \\
\hline Mexico & 8,409 & $28 \%$ \\
\hline Argentina & 5,068 & $17 \%$ \\
\hline Brazil & 4,753 & $16 \%$ \\
\hline Peru & 1,895 & $6 \%$ \\
\hline Chile & 1,666 & $5 \%$ \\
\hline Colombia & 1,451 & $5 \%$ \\
\hline Cuba & 1,320 & $4 \%$ \\
\hline Bolivia & 1,255 & $4 \%$ \\
\hline Puerto Rico & 1,082 & $4 \%$ \\
\hline Venezuela & 914 & $3 \%$ \\
\hline Uruguay & 500 & $2 \%$ \\
\hline Ecuador & 414 & $1 \%$ \\
\hline Dominican Republic & 386 & $1 \%$ \\
\hline El Salvador & 281 & $1 \%$ \\
\hline Guatemala & 276 & $1 \%$ \\
\hline Costa Rica & 267 & $1 \%$ \\
\hline Nicaragua & 214 & $1 \%$ \\
\hline Honduras & 77 & $0 \%$ \\
\hline Panama & 64 & $0 \%$ \\
\hline Paraguay & 54 & $0 \%$ \\
\hline
\end{tabular}

\begin{tabular}{|c|c|c|}
\hline \multicolumn{3}{|c|}{$\begin{array}{c}\text { TABLE } 3 \\
\text { BTAA Collection of Latin American Materials } \\
\text { by Country }\end{array}$} \\
\hline Country & $\begin{array}{l}\text { Number of } \\
\text { Holdings }\end{array}$ & $\begin{array}{c}\text { Percentage of } \\
\text { Latin American } \\
\text { Holdings }\end{array}$ \\
\hline Mexico & 321,924 & $20 \%$ \\
\hline Argentina & 306,219 & $19 \%$ \\
\hline Brazil & 294,435 & $18 \%$ \\
\hline Colombia & 95,091 & $6 \%$ \\
\hline Peru & 93,730 & $6 \%$ \\
\hline Chile & 89,522 & $6 \%$ \\
\hline Venezuela & 72,727 & $5 \%$ \\
\hline Cuba & 54,752 & $3 \%$ \\
\hline Uruguay & 52,550 & $3 \%$ \\
\hline Ecuador & 39,461 & $2 \%$ \\
\hline Bolivia & 33,492 & $2 \%$ \\
\hline Puerto Rico & 32,229 & $2 \%$ \\
\hline Costa Rica & 22,212 & $1 \%$ \\
\hline Guatemala & 20,511 & $1 \%$ \\
\hline Dominican Republic & 18,540 & $1 \%$ \\
\hline Paraguay & 13,806 & $1 \%$ \\
\hline Panama & 11,492 & $1 \%$ \\
\hline Nicaragua & 10,211 & $1 \%$ \\
\hline El Salvador & 9,228 & $1 \%$ \\
\hline Honduras & 7,722 & $0 \%$ \\
\hline
\end{tabular}


percent of these requests were for loans of returnable materials, while only 28 percent were for delivery of nonreturnable scans or copies. The number of requests by publication date steadily increase during the course of the twentieth century, peaking between 2000 and 2011 (see figure 1). There is a steep drop in request volume after 2012, which may reflect the time it takes to acquire and catalog these materials to make them easily discoverable by users.

Thus, physical loans of books published within the past half-century emerge as the BTAA's predominant need when it comes to borrowing Latin American materials from other libraries. In terms of country of publication, the top countries by ILL request volume are Mexico, Argentina, Brazil, Peru, Chile, and Colombia, which also happen to be the top six Latin American countries by BTAA collection size (see tables 2 and 3). They are closely followed by Cuba, Bolivia, and Puerto Rico, for which there is a smaller collective collection but a demonstrated resource-sharing need.

In terms of subject, Spanish and Portuguese Literature (PQ), History of the Americas $(\mathrm{F})$, Social Sciences $(\mathrm{H})$, and other Language and Literature (P, excluding PQ) were the most commonly requested Latin American materials, followed by Fine Arts (N), Philosophy, Psy-

\begin{tabular}{|c|c|c|}
\hline \multicolumn{3}{|c|}{$\begin{array}{c}\text { TABLE } 4 \\
\text { BTAA ILL Requests for Latin American } \\
\text { Materials by Subject }\end{array}$} \\
\hline $\begin{array}{l}\text { Library of } \\
\text { Congress } \\
\text { Classification } \\
\end{array}$ & $\begin{array}{l}\text { Number of } \\
\text { ILL Requests }\end{array}$ & $\begin{array}{l}\text { Percentage of } \\
\text { Latin American } \\
\text { ILL Requests }\end{array}$ \\
\hline$P Q$ & 4,929 & $25 \%$ \\
\hline $\mathrm{F}$ & 4,554 & $23 \%$ \\
\hline $\mathrm{H}$ & 2,745 & $14 \%$ \\
\hline $\mathrm{P}^{*}$ & 1,803 & $9 \%$ \\
\hline $\mathrm{N}$ & 927 & $5 \%$ \\
\hline B & 779 & $4 \%$ \\
\hline$M$ & 762 & $4 \%$ \\
\hline G & 498 & $2 \%$ \\
\hline $\mathrm{J}$ & 492 & $2 \%$ \\
\hline $\mathrm{L}$ & 337 & $2 \%$ \\
\hline$Q$ & 318 & $2 \%$ \\
\hline $\mathrm{K}$ & 304 & $2 \%$ \\
\hline$A$ & 246 & $1 \%$ \\
\hline $\mathrm{D}$ & 225 & $1 \%$ \\
\hline$T$ & 213 & $1 \%$ \\
\hline $\mathrm{R}$ & 198 & $1 \%$ \\
\hline $\bar{Z}$ & 173 & $1 \%$ \\
\hline$C$ & 164 & $1 \%$ \\
\hline$E$ & 130 & $1 \%$ \\
\hline$S$ & 111 & $1 \%$ \\
\hline$U$ & 27 & $0 \%$ \\
\hline $\mathrm{V}$ & 3 & $0 \%$ \\
\hline \multicolumn{3}{|c|}{$P^{*}=$ excluding $P Q$, counted separately. } \\
\hline
\end{tabular}

\begin{tabular}{|c|c|c|}
\hline \multicolumn{3}{|c|}{$\begin{array}{c}\text { TABLE } 5 \\
\text { BTAA Collection of Latin American } \\
\text { Materials by Country }\end{array}$} \\
\hline $\begin{array}{l}\text { Library of } \\
\text { Congress } \\
\text { Classification }\end{array}$ & $\begin{array}{l}\text { Number of } \\
\text { Holdings }\end{array}$ & $\begin{array}{c}\text { Percentage of } \\
\text { Latin American } \\
\text { Holdings }\end{array}$ \\
\hline$P Q$ & 27,611 & $35 \%$ \\
\hline $\mathrm{F}$ & 15,863 & $20 \%$ \\
\hline $\mathrm{H}$ & 12,046 & $15 \%$ \\
\hline $\mathrm{P}^{*}$ & 5,087 & $6 \%$ \\
\hline $\mathrm{J}$ & 3,203 & $4 \%$ \\
\hline $\mathrm{N}$ & 2,389 & $3 \%$ \\
\hline G & 2,071 & $3 \%$ \\
\hline B & 2,030 & $3 \%$ \\
\hline $\mathrm{K}$ & 1,790 & $2 \%$ \\
\hline$L$ & 1,463 & $2 \%$ \\
\hline$M$ & 1,050 & $1 \%$ \\
\hline$T$ & 1,030 & $1 \%$ \\
\hline $\mathrm{Q}$ & 720 & $1 \%$ \\
\hline$D$ & 598 & $1 \%$ \\
\hline$R$ & 597 & $1 \%$ \\
\hline$S$ & 409 & $1 \%$ \\
\hline$C$ & 396 & $0 \%$ \\
\hline$E$ & 372 & $0 \%$ \\
\hline$Z$ & 337 & $0 \%$ \\
\hline$U$ & 182 & $0 \%$ \\
\hline A & 97 & $0 \%$ \\
\hline $\mathrm{V}$ & 33 & $0 \%$ \\
\hline
\end{tabular}


chology, and Religion (B), Music (M), Geography, Anthropology, and Recreation (G), and Political Science (J). With the exception of Music, these highly requested subjects matched the top subjects represented in the BTAA collective collection of Latin American publications (see tables 4 and 5). However, the authors noticed that the ILL requests have a somewhat more even distribution of subjects than the BTAA Latin American collective collection, which is very heavily weighted toward Spanish and Portuguese literature (35\%). The lower percentage of PQs among ILL requests (25\%) could be the result of most of the BTAA libraries having relatively strong Latin American literature collections, thus reducing the need for patrons to request these books from other libraries; it may also reflect a limitation in the methodology related to shorter titles. ${ }^{37}$

When the ILL requests are broken down by subject and country, Mexican literature ( $\mathrm{n}=$ 1,573), Mexican history $(n=1,471)$, and Argentine literature $(n=1,051)$ emerge as the areas of greatest demand for resource sharing, followed by Brazilian literature $(n=877)$ and Mexican social sciences $(n=868)$. The top 18 requested items, each with 10 or more requests, are listed in table 6. It is a diverse list, including a Jewish Argentine periodical, an El Salvadorian

\begin{tabular}{|c|c|c|c|c|}
\hline \multicolumn{5}{|c|}{$\begin{array}{l}\text { TABLE } 6 \\
\text { Items Requested via ILL Most Frequently by BTAA Users }\end{array}$} \\
\hline Title & $\begin{array}{l}\text { Request } \\
\text { Count }\end{array}$ & Country & Format & $\begin{array}{c}\text { Library of } \\
\text { Congress } \\
\text { Classification }\end{array}$ \\
\hline Memoria y balance general & 19 & Argentina & Serial & $\mathrm{H}$ \\
\hline El Diario de hoy & 18 & El Salvador & Serial & AN \\
\hline Estudios sobre la fonología del español del Caribe & 18 & Venezuela & Book & PC \\
\hline Relaciones geográficas del siglo XVI & 17 & Mexico & Book & $\mathrm{F}$ \\
\hline La noche de Tlatelolco: testimonios de historia oral & 16 & Mexico & Book & LA \\
\hline En la sangre & 14 & Mexico & Book & $\mathrm{PQ}$ \\
\hline Página en blanco y staccato & 13 & Puerto Rico & Book & $\mathrm{PQ}$ \\
\hline Rojo amanecer & 12 & Mexico & DVD & PN \\
\hline Aves sin nido & 12 & Peru & Book & $\mathrm{PQ}$ \\
\hline Contrabando & 12 & Mexico & Book & $\mathrm{PQ}$ \\
\hline $\begin{array}{l}\text { Historia verdadera de la conquista de la Nueva } \\
\text { España }\end{array}$ & 12 & Mexico & Book & $\mathrm{F}$ \\
\hline Una modernidad periférica: Buenos Aires, 1920 y 1930 & 11 & Argentina & Book & $\mathrm{F}$ \\
\hline $\begin{array}{l}\text { Soberanías en suspenso: imaginación y violencia en } \\
\text { América Latina }\end{array}$ & 11 & Argentina & Book & $\mathrm{FL}$ \\
\hline El Mundo & 11 & Puerto Rico & Serial & AN \\
\hline $\begin{array}{l}\text { Formas y fórmulas de tratamiento en el mundo } \\
\text { hispánico }\end{array}$ & 11 & Mexico & Book & PC \\
\hline $\begin{array}{l}\text { El retorno de las yolas: ensayos sobre diáspora, } \\
\text { democracia y dominicanidad }\end{array}$ & 10 & $\begin{array}{c}\text { Dominican } \\
\text { Republic } \\
\end{array}$ & Book & $\mathrm{F}$ \\
\hline La revolución es un sueño eterno & 10 & Argentina & Book & $\mathrm{PQ}$ \\
\hline $\begin{array}{l}\text { Ciudadanía política y formación de las naciones: } \\
\text { perspectivas históricas de América Latina }\end{array}$ & 10 & Mexico & Book & JL \\
\hline
\end{tabular}


newspaper, a collection of Caribbean Spanish phonology papers published in Venezuela, a Puerto Rican novel, a Mexican feature film, and essays on diaspora from the Dominican Republic. This diversity is reflected in figure 2, which shows the most requested subjects by Latin American country. While the top three subjects for each country (excluding Puerto Rico) comprise history $(\mathrm{F})$, social sciences $(\mathrm{H})$, and literature $(\mathrm{PQ})$, other highly requested subjects by country vary more widely.

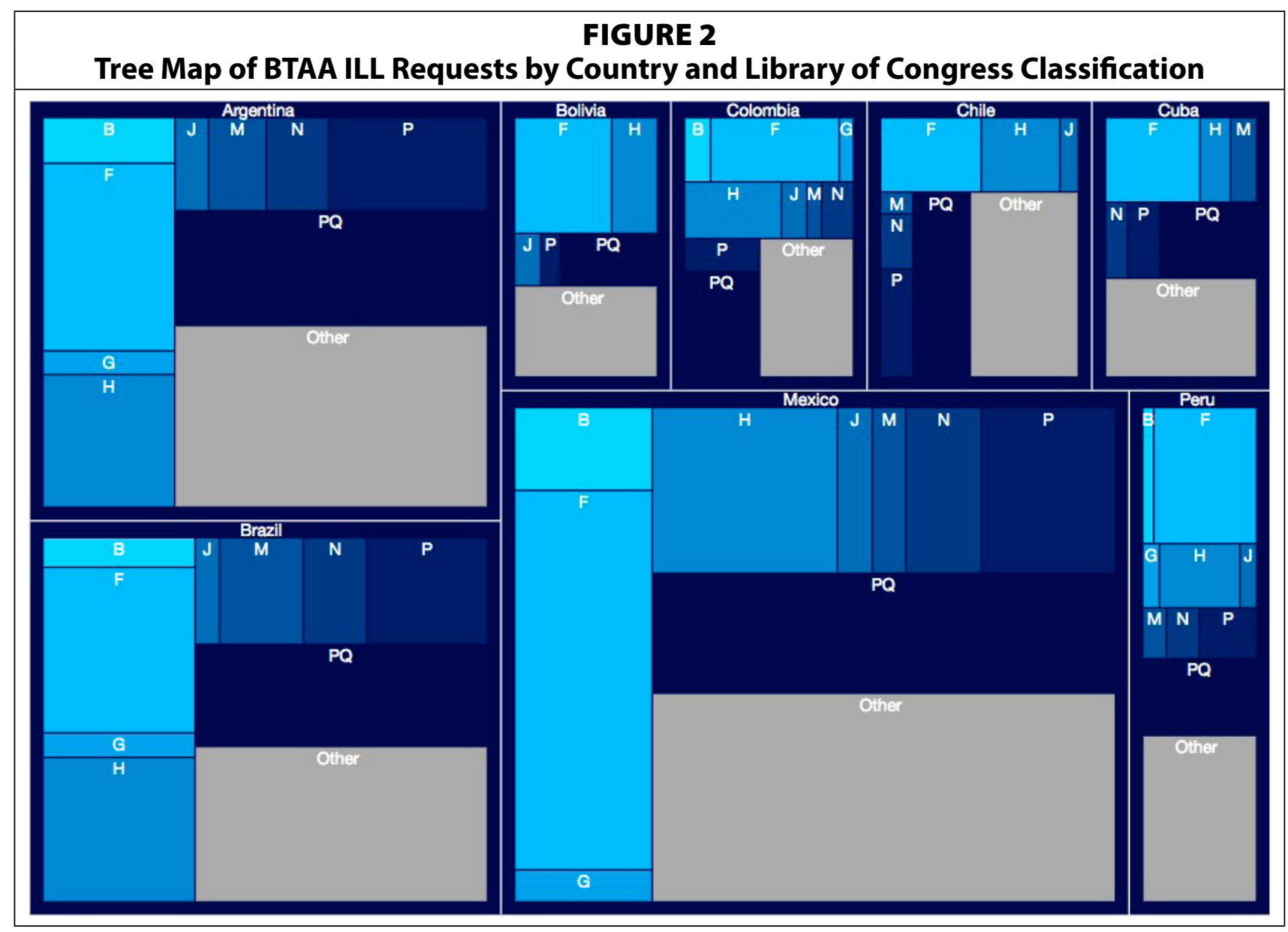

\section{Research Question 2: Which BTAA users and institutions are requesting Latin American materials most frequently?}

The vast majority of Latin American materials requested via ILL are requested by faculty, staff, and graduate students $(91 \%)$, with graduate students dominating $(53 \%)$. These percentages are noticeably higher than the percentage of overall requests ( $82 \%$ and $48 \%$, respectively). Because of the research focus of this audience, these materials may be more likely to support the university's production of scholarship, which may lend an importance to this category of requests that belies its relatively small percentage of the total request volume.

Need across the consortium to borrow Latin American publications from other libraries is not uniform (see figure 3). In fact, there is quite the range in Latin American request volume among Big Ten member libraries, from 581 requests at Michigan State University to 3,916 requests at the University of Maryland. The BTAA institutions that requested the most Latin American materials on average are the University of Maryland (64 per month), the University of Michigan (58 per month), and The Ohio State University (48 per month). Maryland and 


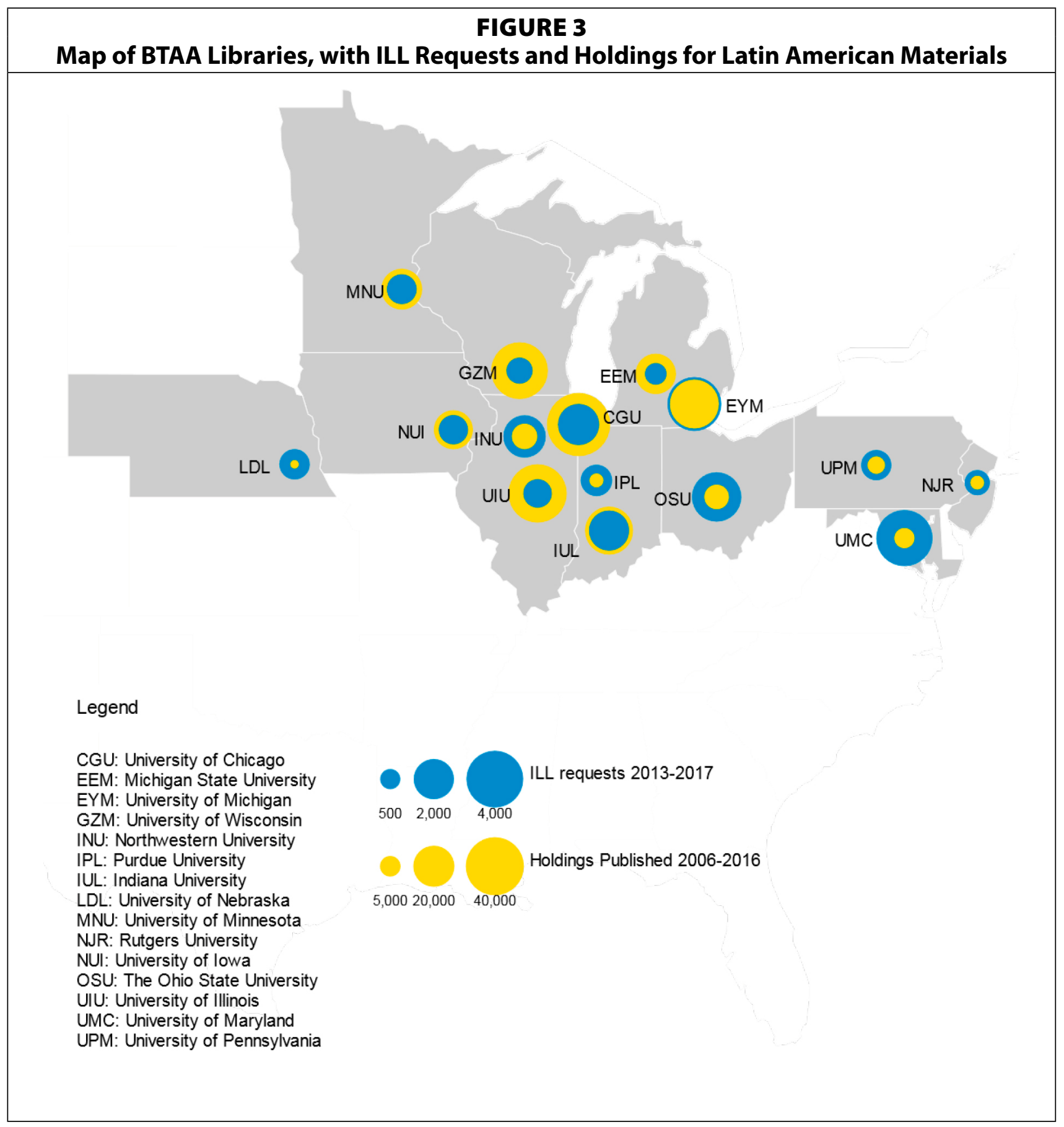

Michigan are among the top five borrowers within the consortium and the top ten borrowers in OCLC; $; 8$ thus, their high volume is unsurprising, especially for Maryland, which has the third smallest Latin American collection in the BTAA. Ohio State's request volume is notable because they are a net lender that prefers to borrow from the OhioLINK consortium before the Big Ten. Their high level of Latin American borrowing may reveal access to international collections to be a benefit of Big Ten membership and reflect a need that is not met through their statewide consortium.

The authors found no correlation between institutions' volume of requests for Latin American materials and the size of their Latin American collections overall (historical collecting), nor between the volume of ILL requests and the volume of acquired materials published 
in the past decade (recent collecting). Some institutions, like Maryland and Northwestern University, rely on the BTAA collection to supplement their relatively smaller Latin American collections. Other institutions, such as Michigan and the University of Chicago, have large historical and contemporary Latin American collections and are still requesting numerous materials via ILL, presumably because there is a high level of research activity in related areas at their institutions. However, there is a correlation between overall UBorrow and ILL activity and Latin American ILL request volume, with high UBorrow and ILL borrowing volume corresponding with higher levels of Latin American ILL requests. Four of the five top borrowers in the BTAA were also among the five top borrowers of Latin American materials, with the University of Minnesota as the only exception.

\section{Research Question 3: What is the success rate for borrowing Latin American} materials from other libraries, and are there any particular areas where BTAA users' needs go unmet?

Of upmost importance is the degree of success our interlibrary loan departments have when trying to borrow these materials from other libraries. Surprisingly (given the reported difficulties in borrowing materials from Latin American libraries), Latin American materials have a very high fill rate $(90 \%)$, and one that is significantly higher than the average for all materials $(83 \%)$. While the data gathered in this study does not fully explain the higher fill rate, a possible reason may be the language of publication; with a limited audience who can read Spanish and Portuguese, these materials may be less likely to be on loan. This hypothesis is supported by the fact that only 9 percent of BTAA ILL requests for Latin American materials were for locally held items, which were likely requested because the local copy was on loan; this percentage is significantly lower than that for all requests made via UBorrow (30\%). It would be interesting to discover if an above-average fill rate also exists for international publications from other regions. The authors explored other patterns related to unfilled requests, and they did not find any countries with noticeably below average fill rate that would raise concerns or suggest the need to ramp up collecting materials from a particular country. However, videos (72\%) and sound recordings (50\%) have significantly lower fill rates than books (90\%) and periodicals (84\%). This divergence correlates with findings from the 2015 RUSA STARS international ILL survey findings, and it likely reflects restrictions in collection development, circulation, and interlibrary loan policies - policies that may merit rethinking to ensure collective access to audiovisual media. ${ }^{39}$ There is also a steep drop in the fill rate for requests for pre-1900 publications, suggesting that public-domain Latin American materials would make an excellent priority for collaborative digitization. ${ }^{40}$

\begin{tabular}{|l|c|c|c|c|}
\hline \multicolumn{4}{|c|}{ TABLE 7 } \\
& $\begin{array}{c}\text { Libraries that Fill BTAA ILL Requests } \\
\text { Publications }\end{array}$ & \multicolumn{3}{c|}{ All Publications } \\
\hline Supplier & $\begin{array}{c}\text { Number of } \\
\text { Requests Filled }\end{array}$ & $\begin{array}{c}\text { Percentage } \\
\text { Filled }\end{array}$ & $\begin{array}{c}\text { Number of } \\
\text { Requests Filled }\end{array}$ & $\begin{array}{c}\text { Percentage } \\
\text { Filled }\end{array}$ \\
\hline BTAA Library & 15,940 & $60.7 \%$ & 985,246 & $54.9 \%$ \\
\hline Other U.S. Library & 9,642 & $36.7 \%$ & 768,082 & $42.8 \%$ \\
\hline Library Abroad & 687 & $2.6 \%$ & 40,916 & $2.3 \%$ \\
\hline
\end{tabular}


Research Question 4: To what degree do BTAA libraries rely on the consortial collection and the national collection to obtain Latin American materials requested by their users?

Finally, the authors investigated the libraries filling BTAA ILL requests for Latin American materials, seeking to understand the degree to which our institutions rely on the Big Ten collective collection and the larger national collection to obtain these materials for our users. As seen in table 7, 61 percent of successful BTAA ILL requests are filled by another BTAA library, which is greater than the percentage for all ILL requests (55\%), demonstrating an increased reliance on the BTAA collection for Latin American materials. The majority of BTAA libraries are actively collecting Latin American materials, which means a strong collection for supporting consortial resource sharing already exists. The correlation between the number of Latin American holdings in a library's collection and the number of BTAA ILL requests that library filled, as well as the higher degree to which our libraries rely on the BTAA collective collection for these materials, is clearly visible in figure 4 . The greatest reliance on the BTAA collection is for materials published in Uruguay (62\%), Ecuador (63\%), and Peru (64\%). Conversely, member libraries rely on the BTAA collection the least for materials published in Cuba (45\%), El Salvador (48\%), and Puerto Rico (49\%). For those two countries and U.S. territory, the top lenders outside the Big Ten reflect other consortial relationships and memberships in which one or more BTAA libraries participate (such as Ivy Plus Libraries, RapidILL ARL reciprocal list, and Center for Research Libraries) as well as the largest Latin American collections in the United States (the Library of Congress, University of Texas at Austin, and New York Public Library). Ultimately, the percentage of Latin American materials borrowed from abroad is quite small at 2.6 percent $(n=687)$. The top supplying countries were Spain $(n=117)$, Canada $(\mathrm{n}=88)$, Germany $(\mathrm{n}=76)$, and Mexico $(\mathrm{n}=73)$, while Latin American libraries from countries

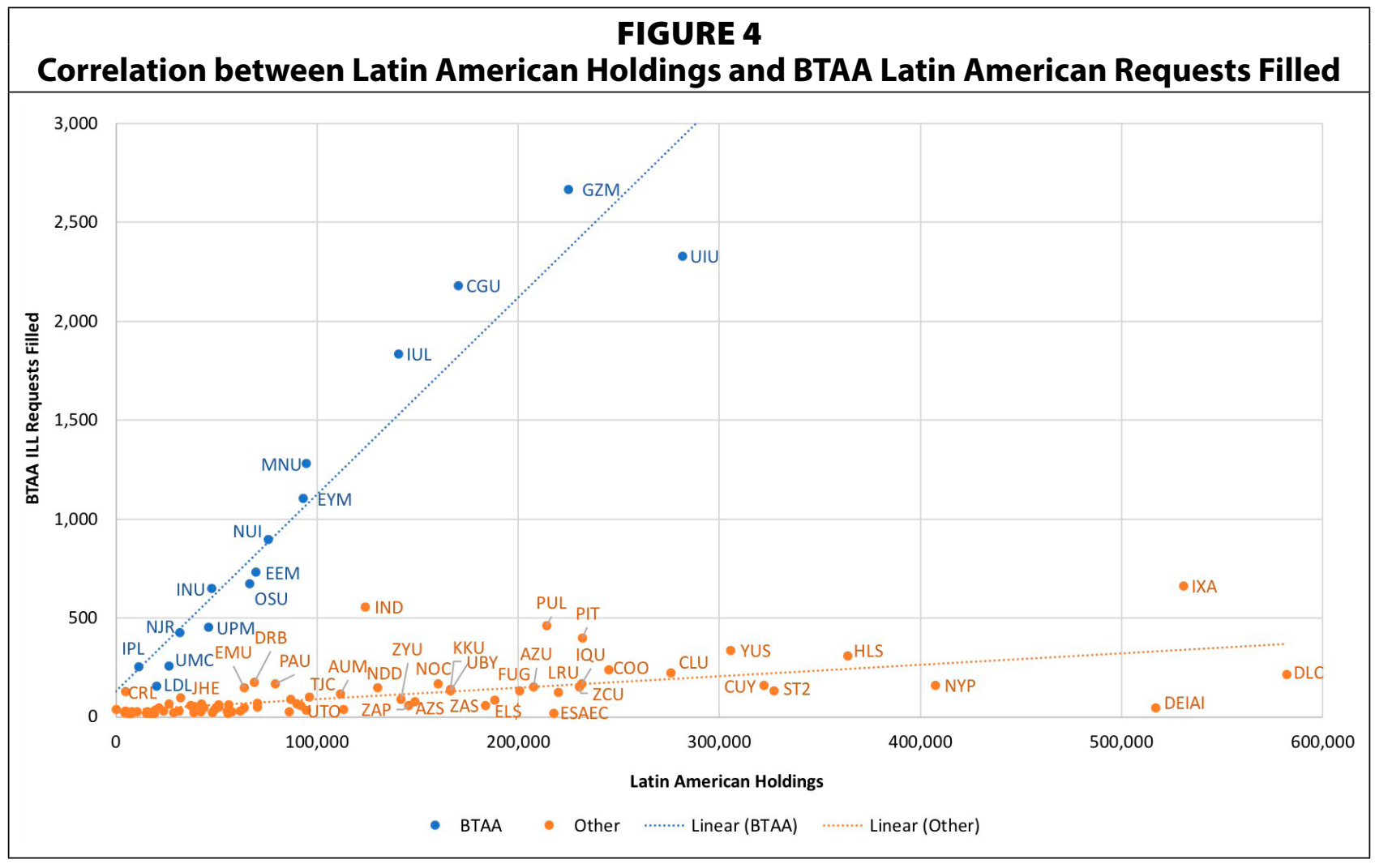


other than Mexico filled only 26 requests. These data reinforce the Big Ten Academic Alliance's strong reliance on the consortial and national collection to support researchers' need for Latin American publications, underscoring the need for greater cooperation in collecting to build distinctive collections that support resource sharing.

\section{Limitations}

One limitation of this study is the quality of the MARC record cataloging and of the language detection algorithm. The authors performed accuracy testing on data samples to gauge the extent that automated data analysis may have triggered false positives or negatives. The authors' prior experience has shown that MARC records for publications from Spain (SP) are sometimes miscoded for El Salvador (ES). Manual analysis of MARC records for books owned by BTAA member libraries with a country code of ES revealed that 92 percent were published in El Salvador, 4 percent published in Spain, 2 percent published in Estonia, and 2 percent published in other countries ( $8 \%$ false positives). Where there are known cataloging errors, mitigation strategies can be used; for example, to improve accuracy for this study, a filter was added to discard any publications with a country code of ES and the European city names of Madrid, Barcelona, or Tallinn in the place of publication field (260a). Accuracy testing of Google's language detection for Spanish and Portuguese titles performed on 5,000 UMD ILL requests suggests that our methodology may have missed 8 percent of books published in Spanish or Portuguese (8\% false negatives), and short literature titles with proper names are more likely to be omitted (see note 7). Any false positives from Google Translate were discarded when metadata from the MARC record was checked for language. Since the percentage of false positives and negatives was less than 10 percent in each case, the authors feel that the methodology's automation and the resulting ability to work with large consortial data sets outweighs its limitations, especially if one's goal is to identify broad trends in consortial resource sharing. However, it is worth noting that the accuracy of Google's language detection varies significantly from language to language, and using this tool to identify ILL requests for specific languages with non-Roman scripts would not be advisable (although it may be possible to use it to separate requests with clearly identifiable Roman script titles from those without, leaving a smaller batch for further analysis).

Another limitation is the lack of borrowing data from integrated library systems and other consortial borrowing systems. The authors did not attempt to collect local circulation data from BTAA member libraries, and their data from ILLiad does not include Latin American materials borrowed from BorrowDirect (University of Chicago), OhioLINK (Ohio State), or USMAI (University of Maryland), just to name a few consortial borrowing systems in which BTAA member libraries also participate. As such, this methodology cannot be used to determine the full extent of an institution's demand for Latin American materials or other international collections, especially for those belonging to multiple consortia.

\section{Conclusion}

Understanding the borrowing needs of users in the Big Ten Academic Alliance is a critical first step in working toward cooperative collection development of international publications within the consortium. A clear relationship exists between BTAA Latin American collections and resource sharing in terms of collective collection strengths and ILL borrowing volume and fill rate. Patterns in the ILL data reveal areas of high demand (such as print books related to 
history, social sciences, and literature published in Mexico, Argentina, Brazil, Peru, Chile, and Colombia) that should prove useful in tailoring analysis of BTAA holdings to inform models for cooperative collection development. The ILL data also reveal areas of unmet need (namely pre-1900 publications, sound recordings, and videos), which may prompt reexamination of digitization priorities and local policies for acquisitions and circulation to improve access to these types of content. At the same time, variance in ILL requests by country demonstrates that one cannot view Latin America as a single entity when making collections decisions, and the need for a more nuanced approach by country or province is likely true for other world regions. The authors hope this study can serve as a model for other consortia and groups interested in developing collective collections in area studies. Due to its limitations, this methodology is best used for identifying broad trends, rather than informing specific selection decisions. These broad trends can be used to inform a larger, collaborative collecting strategy or smaller pilots focused on minimizing duplication of particular content between select institutions. To this end, ILL practitioners and bibliographers need to share data and engage in conversations with each other and with those setting collection management priorities. Together, academic librarians should use resource sharing and collections data to inform cooperative collection development in area studies to build distinctive international collections that support researchers across our institutions.

\section{Acknowledgments}

The authors would like to recognize and express our appreciation to the Big Ten Academic Alliance ILL directors and system administrators for sharing their interlibrary loan borrowing data for use in this study: Melissa Eighmy Brown (University of Minnesota); Cen Cheng (Michigan State University); Kurt Munson and Elizabeth Fraser (Northwestern University); Heather Weltin and Stephanie Harris (University of Wisconsin); Emily Campbell and Ralph Johnson (University of Michigan); David Larsen (University of Chicago); Meg Massey (Pennsylvania State University); Joyce Melvin (University of Nebraska); Brian Miller (The Ohio State University); Amy Paulus (University of Iowa); Rita Rogers and Keith Welch (Indiana University); Glenn Sandberg and Christopher Sterback (Rutgers University); Cherié Weible (University of Illinois); and Amy Winks (Purdue University). 


\section{APPENDIX A. ILLiad Custom Request Searches for ILL Data Gathering}

\section{Loans with OCLC Numbers}

Search clauses:

Transactions.ProcessType Equals Borrowing

Transactions.RequestType Equals Loan

Transactions.CreationDate Is greater than 6/1/2012

Transactions.ESPNumber Is not blank

Columns:

ESPNumber, LoanTitle, Status, CreationDate, TransactionStatus, LendingLibrary

\section{Articles with OCLC Numbers}

Search clauses:

Transactions.ProcessType Equals Borrowing

Transactions.RequestType Equals Article

Transactions.CreationDate Is greater than 6/1/2012

Transactions.ESPNumber Is not blank

Columns:

ESPNumber, PhotoJournalTitle, PhotoArticleTitle, Status, CreationDate, TransactionStatus, LendingLibrary

\section{Loans without OCLC Numbers}

Search clauses:

Transactions.ProcessType Equals Borrowing

Transactions.RequestType Equals Loan

Transactions.CreationDate Is greater than 6/1/2012

Transactions.ESPNumber Is blank

Columns:

LoanTitle, Status, CreationDate, TransactionStatus, LendingLibrary

\section{Articles without OCLC Numbers}

Search clauses:

Transactions.ProcessType Equals Borrowing

Transactions.RequestType Equals Article

Transactions.CreationDate Is greater than 6/1/2012

Transactions.ESPNumber Is blank

Columns:

PhotoJournalTitle, PhotoArticleTitle, Status, CreationDate, TransactionStatus, LendingLibrary 


\section{APPENDIX B. Access Queries for ILL Data Gathering}

\section{Loans with OCLC Numbers}

SELECT ESPNumber, REPLACE(REPLACE(LoanTitle, CHR(13), “), CHR(10), “), Status, CreationDate, TransactionStatus, t.LendingLibrary

FROM Transactions AS t LEFT JOIN Users AS u ON t.Username = u.Username

WHERE CreationDate > \#6/1/2012\#

AND ProcessType $=$ "Borrowing"

AND RequestType $=$ "Loan"

AND ESPNumber IS NOT NULL;

\section{Articles with OCLC Numbers}

SELECT ESPNumber, REPLACE(REPLACE(PhotoJournalTitle, CHR(13), “), CHR(10), “) + "

'+ REPLACE(REPLACE(PhotoArticleTitle, CHR(13), “), CHR(10), "), Status, CreationDate, TransactionDate, t.LendingLibrary

FROM Transactions AS t LEFT JOIN Users AS u ON t.Username = u.Username

WHERE CreationDate > \#6/1/2012\#

AND ProcessType $=$ "Borrowing"

AND RequestType $=$ "Article"

AND ESPNumber IS NOT NULL;

Note: this query concatenates journal title and loan title into one string, to improve language detection.

\section{Loans without OCLC Numbers}

SELECT REPLACE(REPLACE(t.LoanTitle, CHR(13), “), CHR(10), “), u.Status, t.CreationDate, t.TransactionStatus, t.LendingLibrary

FROM Transactions AS t LEFT JOIN Users AS u ON t.Username = u.Username

WHERE ESPNumber IS NULL

AND ProcessType $=$ "Borrowing"

AND RequestType $=$ "Loan"

AND CreationDate > \#6/1/2012\#;

\section{Articles without OCLC Numbers}

SELECT REPLACE(REPLACE(PhotoJournalTitle, CHR(13), “), CHR(10), “) + " " + REP LACE(REPLACE(PhotoArticleTitle, CHR(13), “), CHR(10), “), u.Status, t.CreationDate, t.TransactionStatus, t.LendingLibrary

FROM Transactions AS t LEFT JOIN Users AS u ON t.Username = u.Username

WHERE CreationDate $>\# 6 / 1 / 2012 \#$

AND ProcessType $=$ "Borrowing"

AND RequestType $=$ "Article"

AND ESPNumber IS NULL;

Note: this query concatenates journal title and loan title into one string, to improve language detection. 


\section{Notes}

1. Beaubien et al. attest to the long and active history of the BTAA ILL directors in their 2006 article, which itself serves as an excellent example of earlier collaboration within this group. Anne K. Beaubien et al., "Challenges Facing High Volume Interlibrary Loan Operations: Baseline Data and Trends in the CIC Consortium," College \& Research Libraries 67, no. 1 (2006): 63-84.

2. Sarah Pritchard et al., Big Ten Academic Alliance UBorrow Program Evaluation (Nov. 2017), available online at https://www.btaa.org/docs/default-source/programevals/uborrow-program-evaluation-nov2017.pdf [accessed 7 March 2018].

3. Christopher Cronin et al., "Strength in Numbers: Building a Consortial Cooperative Cataloging Partnership," Library Resources \& Technical Services 61, no. 2 (2017): 102-16; Big Ten Academic Alliance, Next Generation Discovery to Delivery Systems: A Vision (2017), available online at https://www.btaa.org/library/discover-to-deliver/ reports [accessed 7 March 2018]; Big Ten Academic Alliance, Principles and Protocols for the Interlibrary Loan of Special Collections (2018), available online at https://www.btaa.org/library/reciprocal-borrowing/special-collections [accessed 7 March 2018].

4. Big Ten Academic Alliance, "Library Conference 2017," available online at https://www.btaa.org/about/ calendar/conferences/library/2017/home [accessed 7 March 2018].

5. Lorcan Dempsey, Constance Malpas, and Brian Lavoie, "Collection Directions: The Evolution of Library Collections and Collecting," portal: Libraries and the Academy 14, no. 3 (2014): 414.

6. Doug Way, "Transforming Monograph Collections with a Model of Collections as a Service," portal: $L i-$ braries and the Academy 17, no. 2 (2017): 286.

7. Way, "Transforming Monograph Collections with a Model of Collections as a Service," 290.

8. Daniel Dollar, "Collections Are a Service" (presentation, Charleston Conference, Nov. 6, 2015), PowerPoint slides available online at https://www.slideshare.net/DanielDollar/collections-as-a-service [accessed 25 June 2017].

9. Manuel Ostos, "What Do They Use? Where Do They Get It? An Interdisciplinary Citation Analysis of Latin American Studies Faculty Monographs, 2004-2013," College \& Research Libraries 78, no. 5 (2017): 567-77.

10. Julie Linden, Sarah Tudesco, and Daniel Dollar, "Collections as a Service: A Research Library's Perspective," College \& Research Libraries 79, no. 1 (2018): 86-99; Lorcan Dempsey and Constance Malpas, "Academic Library Futures in A Diversified University System," in Higher Education in the Era of the Fourth Industrial Revolution, ed. Nancy W. Gleason (Singapore: Palgrave Macmillan, 2018), 65-89.

11. Susan Edwards, Lynn Jones, and Scott McGinnis, "Big Data for Big Questions: Assessing the Impact of Non-English Language Sources on Doctoral Research at Berkeley," Proceedings of the Association of College and Research Libraries (Chicago, IL: American Library Association, 2017).

12. Dan C. Hazen, "Researching Library Support for International Studies: Successes to Celebrate, Goal Posts to Move," College \& Research Libraries 75, no. 4 (2014): 418-21.

13. For an analysis of how international collections serve a national community of scholars through interlibrary loan, see Joe Lenkart et al., "Measuring and Sustaining the Impact of Less Commonly Taught Language Collections in a Research Library," College \& Research Libraries 76, no. 2 (2015): 222-33. For recent examples of the importance of ILL in supporting Asian Studies scholars, see Bonnie Brown Real, Mary Rader, and Meng-fen Su, "Supporting the Changing Research Practices of Asian Studies Scholars at The University of Texas at Austin" (2017), 6, available online at http://hdl.handle.net/2152/62941 [accessed 21 November 2018]; and Karen Stoll Ferrell, "Supporting the Changing Research Practices of Asian Studies Scholars at Indiana University-Bloomington" (2017), 7, available online at http://hdl.handle.net/2022/21920 [accessed 21 November 2018].

14. For more information about the 1998, 2007, 2011, and 2015 surveys, see Nancy E. Elkington and Dennis Massie, "The Changing Nature of International Resource Sharing: Risks and Benefits of Collaboration," Interlending \& Document Supply 27, no. 4 (1999): 148-54; Tina Baich et al., "Lending and Borrowing across Borders: Issues and Challenges with International Resource Sharing," Reference E User Services Quarterly 49, no. 1 (2009): 55-64; Tina Baich and Heather Weltin, "Going Global: An International Survey of Lending and Borrowing across Borders," Interlending \& Document Supply 40, no. 1 (2012): 37-42; and Kurt Munson et al., "The World Is Your Library, or the State of International Interlibrary Loan in 2015," Interlending $\mathcal{E}$ Document Supply 44, no. 2 (2016): 44-57.

15. Kurt Munson and Hilary H. Thompson, "Giving Your Patrons the World: Barriers to, and the Value of, International Interlibrary Loan," portal: Libraries and the Academy 18, no. 1 (2018): 17-34. For more on using the United Nations Human Development Index as a framework for understanding international ILL activity, see pages 20-24. 


\section{Borrowing Latin American Materials in the Big Ten Academic Alliance 785}

16. Megan Gaffney, "Interlibrary Loan between the United States and Latin America: The Current Landscape," paper presented at the IFLA Document Delivery and Resource Sharing Satellite meeting, August 10-11, 2016, Washington, DC, available online at http://library.ifla.org/1929/1/S06-2016-gaffney-en.pdf [accessed 12 July 2017].

17. Linda Frederiksen, Margaret Bean, and Heidi Nance, "Latin America and the Caribbean," in Global Resource Sharing (Cambridge, MA: Chandos Publishing, 2011), 122-24.

18. LeEtta Schmidt, "Interlibrary Lending in Mexican, Caribbean, Central American, and South American Libraries," Journal of Interlibrary Loan, Document Delivery and Electronic Reserve 24, no. 5(2014).

19. Munson and Thompson, "Giving Your Patrons the World," 29-31.

20. Manuel Ostos and Lisa Gardinier, "Spanish-language Print Materials within Academic Consortia: Assessing the Impact of Resource Sharing in Two Academic Libraries," Journal of Academic Librarianship 44, no. 2 (2018): 295-99.

21. Beaubien et al., "Challenges Facing High-Volume Interlibrary Loan Operations”; Doris M. Munson and Suzanne Milton, "The Orbis Cascade Merger and Its Impact on Patron-Initiated Borrowing," Journal of Access Services 6, no. 3 (2009): 346-58; Anita Cook and Dennis J. Smith, "The Ohio Library and Information Network: Resource Sharing at Its Best," Journal of Interlibrary Loan, Document Delivery E Electronic Reserve 21, no. 5 (2011): 219-25; Joseph A. Williams and David E. Woolwine, "Interlibrary Loan in the United States: An Analysis of Academic Libraries in a Digital Age," Journal of Interlibrary Loan, Document Delivery \& Electronic Reserve 21, no. 4 (2011): 165-83; David P. Atkins, Judy T. Greenwood, and Pambanisha Whaley, "Benchmarking and Pondering ASERL Interlibrary Loan Operations, 2010 and 2013," Interlending E Document Supply 42, no. 1 (2014): 16-25; Leetta M. Schmidt and Dennis Smith, "The Florida State Libraries Resource Sharing Initiative: Did the Predictions Pan Out?" Journal of Interlibrary Loan, Document Delivery \& Electronic Reserve 24, no. 3/4 (2014): 63-76; Joanna Duy and Vincent Larivière, "Relationships between Interlibrary Loan and Research Activity in Canada," College $\mathcal{E}$ Research Libraries 75, no. 1 (2014): 5-19; C.J. de Jong and Linda J. Frederiksen, "CARL Libraries-a Canadian Resource-Sharing Experience," Interlending \& Document Supply 43, no. 1 (2015): 22-33; Gwen Evans and Theda Schwing, "OhioLINK-Recent Developments at a United States Academic Library Consortium," Interlending $\mathcal{E}$ Document Supply 44, no. 4 (2016): 172-77.

22. Beaubien et al., "Challenges Facing High Volume Interlibrary Loan Operations"; Munson and Milton, "The Orbis Cascade Merger and Its Impact on Patron-Initiated Borrowing"; Atkins, Greenwood, and Whaley, "Benchmarking and Pondering ASERL Interlibrary Loan Operations, 2010 and 2013"; Schmidt and Smith, "The Florida State Libraries Resource Sharing Initiative"; Jared Harmon, "Is It Good to Share? An Effectiveness Study of the Indiana Share Program," Journal of Interlibrary Loan, Document Delivery and Electronic Reserve 22, no. 5 (2012): 254-68; Cyril Oberlander and Edwin Rivenburgh, "The IDS Project: Promoting Library Excellence through Community and Technology," Interlending \& Document Supply 40, no. 2 (2012): 76-80.

23. Munson and Milton, "The Orbis Cascade Merger and Its Impact on Patron-Initiated Borrowing"; Schmidt and Smith, "The Florida State Libraries Resource Sharing Initiative"; and Peter D. Collins, "User Analysis in the Borrow Direct Marketplace," Interlending \& Document Supply 43, no. 4 (2015): 179-81.

24. Danuta A. Nitecki, Carol Jones, and Jeffrey Barnett, "Borrow Direct: A Decade of a Sustained Quality Book-Lending Service," Interlending \& Document Supply 37, no. 4 (2009): 192-98.

25. Lynn Wiley, Tina Chrzastowski, and Stephanie Baker, "A Domestic Monograph Collection Assessment in Illinois Academic Libraries: What Are We Buying and How Is It Used?" Interlending \& Document Supply 39, no. 4 (2011): 167-75.

26. Wiley, Chrzastowski, and Baker, "A Domestic Monograph Collection Assessment in Illinois Academic Libraries," 169.

27. Chandra Prabha and Edward O'Neill, "Interlibrary Borrowing Initiated by Patrons," Journal of Library Administration 34, no. 3 (2001): 329-38; Edward T. O'Neill and Julia A. Gammon, "Consortial Book Circulation Patterns: The OCLC-OhioLINK Study," College \& Research Libraries 75, no. 6 (2014): 791-807.

28. Nitecki, Jones, and Barnett, "Borrow Direct," 195.

29. Chandra Prabha, "Characteristics of Articles Requested through OCLC Interlibrary Loan Chandra," Journal of Library Administration 34, no. 1/2 (2001): 179-86.

30. OhioLINK Collection Building Task Force, Julia Gammon, and Edward T. O'Neill, OhioLINK OCLC Collection and Circulation Analysis Project 2011, OCLC Research, 11-13, available online at https://www.oclc.org/ research/publications/library/2011/2011-06r.html [accessed 23 May 2018].

31. Although it is a U.S. territory, the Commonwealth of Puerto Rico was included in this study because it has its own MARC country code and its materials are purchased through a Caribbean vendor; Spanish language materials are generally excluded from U.S. distribution channels.

32. The OCLC Borrower Resource Sharing Stats Report does have a language field; but, unfortunately, this data stopped populating in the reports in September 2016. 
33. Examples of scripts employed as part of this research study are available online at https:/github.com/ austinfsmith/LACC [accessed 19 December 2018].

34. Michal Mimino Danilak, Langdetect 1.0.7 (Licensed under the Apache License, Version 2.0., last modified Oct. 3, 2016), available online at https://pypi.python.org/pypi/langdetect [accessed 26 August 2018].

35. WorldCat Search API, OCLC Developer Network, OCLC Online Computer Library Center, available online at https://www.oclc.org/developer/develop/web-services/worldcat-search-api.en.html [accessed 9 August 2019].

36. Example of an expert search for holdings by country for an institution with one OCLC symbol: cp: ag and li: umc. For an institution with multiple OCLC symbols: cp: ag and (li: inu or li: inm or li: inl). These expert searches can be further refined to search for book holdings by Library of Congress classification for the last decade: $\mathrm{dt}=$ "bks" and yr:2006-2016 and li:UMC and cp:ag and $\left(\mathrm{lc}=\mathrm{B} 1^{*}\right.$ or $\mathrm{lc}=\mathrm{B} 2 *$ or $\mathrm{lc}=\mathrm{B} 3^{*}$ or ... ). For a comprehensive list of search indexes and instructions on using them, see "Searching WorldCat Indexes," Librarian's Toolbox, OCLC Computer Library Center (last modified Jan. 3, 2018), available online at https://help.oclc. org/Librarian_Toolbox/Searching_WorldCat_Indexes/ [accessed 24 January 2018].

37. PQ comprises 35 percent of the BTAA's collective collection of Latin American materials (nearly twice that of the next highest call number range); and, for 87 percent of the BTAA libraries, PQ represents the largest number of Latin American holdings published between 2006 and 2016. However, further testing revealed that Google's Language Detection Library has difficulty correctly identifying the language of very short titles, especially those composed of proper nouns (example: the novels Jardines de Kensington by Rodrigo Fresán and Rayuela by Julio Cortázar). As a result, ILL requests for Spanish and Portuguese literature are more likely to be accidentally omitted by this methodology than other types of Latin American books.

38. Pritchard et al., Big Ten Academic Alliance UBorrow Program Evaluation, 5; "Resource Sharing Facts and Statistics," WorldShare ${ }^{\circledR}$ Interlibrary Loan, OCLC Online Computer Library Center, available online at https:// www.oclc.org/en/worldshare-ill/statistics.html [accessed 26 April 2018].

39. Collection development policies for media might require region one, region free, and/or an institutional license for purchasing media, which may not be available for Latin American films and sound recordings. Also, while members of the Big Ten are very generous when lending media, restrictions on lending media are still prevalent in the national and global resource sharing communities.

40. The BTAA has a history of collaborating on initiatives related to the digitization of legacy print collections, including its involvement with the Google Books Search Project and its role in the founding and ongoing governance of the HathiTrust Digital Library. For more on strategic collaboration in digitization, see Mary Coutts, Stepping Away from the Silos: Strategic Collaboration in Digitisation (Cambridge, MA: Chandos Publishing, 2016). 